\title{
THE CRITICAL SUCCESS FACTORS OF IMPLEMENTING HUMAN RESOURCE INFORMATION SYSTEMS: AN EXPLORATORY ANALYSIS OF PERSONNEL MANAGEMENT
}

\author{
EKAPARNA GOSWAMI ${ }^{1} \&$ DR. ANITA VENAIK ${ }^{2}$
}

${ }^{1}$ Student, Amity Business School, Institutional Address: Amity Business School, Amity University Campus, Noida, Uttar Pradesh, India

${ }^{2}$ Professor, Amity Business School, Institutional Address: Amity Business School, Amity University Campus, Noida, Uttar Pradesh, India

\section{ABSTRACT}

In this paper, a study is done on the implementation of Human Resource Information System (HRIS) and the critical factors for its successful implementation. Here, based on earlier research work on HRIS, various factors have been chosen. Attempt has been made to pinpoint the different stages of HRIS implementation. Given the potential of information systems in today's business world, the widespread use of HRIS in personnel management is described in this paper. The results and implications of the analysis is discussed as well. Workforce performance has been comparatively improved after HRIS implementation. For future, areas of concern for successful implementation of the information systems in HR function is further added.

KEYWORDS: HRIS, Human Resource, Information System, Implementation, Success Factors

Received: Jan 05, 2018; Accepted: Jan 25, 2018; Published: Feb 07, 2018; Paper Id.: IJMPERDFEB2018154

\section{INTRODUCTION}

\subsection{Human Resource Information System (HRIS)}

HRIS is the system that is used for collecting and processing data from every user so that they can use for day-today work like designing, deciding, reporting to shareholders and contributors. HRIS is concisely outlined as an interconnecting device that helps to process data relating to the workforce in a company.

The system is able to be a strategic player in the organization and completely changing the scenario of the organization. HRIS has been able to create a benchmark in the business world with its excellence.

\subsection{Evolution of HRIS Process: Then vs Now}

During the $19^{\text {th }}$ century, the main target had begun to shift to HRIS as a great tool for human resource because of the quality. HRIS emerged not solely in HR but other departments as well.

In the late $80 \mathrm{~s}$, workplace automation began to display on the landscape, and HRIS were developed as a special class of workplace automation systems.

Nowadays, HRIS is a perfect combination of many standardized sorts of processing information and data. Alongside workplace automation system abilities, present HRIS embrace options of operative systems, decision 
support systems, communication systems, and systems with elements of latest engineering.

Evidence are found among corporate culture that well-implemented HRIS could supply valuable data to the firm in controlling each and every employee i.e. the organization's human resources. The information that process out of the HIRS are organized in a perfect manner and can be used for making worthful decisions regarding the organization's goals and objectives.

If we are able to deal with the challenges of the HRIS there is no way the organization will not be able to taste the fruit of their investment.

\subsection{Human Resource/Personnel Management}

Mohapatra in 2009 described that in all organizations, HR business unit could also be a standard department. Whereas other primary departments of an organizations have been able to adapt to the technological advancements, the human resources of the HR department are trying hard to catch up to the modernization. Human resources are always termed as the capital investment in an organization still the department as its employees are not able to achieve full access to the technology.

So, in order to achieve productivity and efficiency in the HR department it is necessary for all to adapt to the change and computerized their all systems and learn the new technical tricks.

\subsection{Success and Failure of HRIS Implementation}

The Secretary general has provided in the $13^{\text {th }}$ report regarding the general worth of the HRIS project amounted to US\$ seventy-eight 6 million. If the system is successfully implemented there will be changes in all the parts and processes of business units. If all these processes are streamlined, the organizations will achieve a new level of growth and profits. Repetition and duplication of data and processes will them be checked and organizations will get authentic data for all the processes. The processes will also be customized according to the will of the users and there will be a high alert system.

The advantages of HRIS cannot be listed in a single go, but there are also many challenges and disadvantages that an organization are risk of facing. So, during the planning phase of the HRIS implementation the organizations should be made aware of the all possible risks and challenges, so that they can prepare their lower, middle and top level of the organizations. The company has to be ready with a risk plan that can create alternative outcomes for the companies.

\subsection{Scope of The Study}

The scope provided in the study talks about achieving an insight of HRIS along with explaining its impact on employees.

This study highlights that organizations that have successfully implemented HRIS and are using it for so many years may have to reconsider the system. The employees using the HRIS may not attain efficiency in their productivity and their growth may become stagnant. Apart from the common factors that can succeed HRIS, the readers will get to know which factors can also enhance employees' skills and growth.

\section{LITERATURE REVIEW}

In reviewing the HRIS success literature, we tend to find a large number of analysis on HRIS, its implementation and therefore the success/failure factors. The objectives of every analysis paper vary with each other. So, the following reviews are ascendingly arranged as per their publication years. 


\begin{tabular}{|c|c|c|c|c|}
\hline SI. No. & Authors & Titles & Methodology & Findings \\
\hline 1 & $\begin{array}{l}\text { K. A. } \\
\text { Kovach, } \\
\text { Allen A. } \\
\text { Hughes, Paul } \\
\text { Fagan, and } \\
\text { Patrick G. } \\
\text { Maggitti, } \\
2002\end{array}$ & $\begin{array}{l}\text { Administrative and } \\
\text { Strategic Advantages } \\
\text { of HRIS }\end{array}$ & $\begin{array}{l}\text { Related research } \\
\text { papers }\end{array}$ & $\begin{array}{l}\text { Scalability, set-up, functionality and } \\
\text { compatibility are among the most } \\
\text { important items that deserving } \\
\text { attention and forethought in HRIS } \\
\text { implementation. }\end{array}$ \\
\hline 2 & $\begin{array}{l}\text { H.G._Parsa, } \\
2007\end{array}$ & $\begin{array}{l}\text { Critical Factors in } \\
\text { Implementing HRIS in } \\
\text { Restaurant Chains }\end{array}$ & Past literature review & $\begin{array}{l}\text { Financial resources, culture, and } \\
\text { computer competency are better } \\
\text { predictors of any successful } \\
\text { implementation of HRIS in restaurant } \\
\text { chains. }\end{array}$ \\
\hline 3 & $\begin{array}{l}\text { Michel } \\
\text { Delorme, } \\
\text { Michel } \\
\text { Arcand } \\
(2009)\end{array}$ & $\begin{array}{l}\text { HRIS implementation } \\
\text { and deployment: a } \\
\text { conceptual framework } \\
\text { of the new roles, } \\
\text { responsibilities and } \\
\text { competences for HR } \\
\text { professionals }\end{array}$ & $\begin{array}{l}\text { Related research } \\
\text { papers }\end{array}$ & $\begin{array}{l}\text { Evolution of the roles and } \\
\text { responsibilities of HR professionals } \\
\text { from a traditional perspective to a new } \\
\text { strategic perspective for HRIS } \\
\text { success. }\end{array}$ \\
\hline 4 & $\begin{array}{l}\text { A. Malviya, } \\
\text { S. Kumar, N. } \\
\text { Hemrom and } \\
\text { K. C. } \\
\text { Kothari, } 2009\end{array}$ & $\begin{array}{l}\text { Challenges of } \\
\text { Implementing HRIS in } \\
\text { a Public Sector } \\
\text { Enterprise. }\end{array}$ & $\begin{array}{l}\text { Data migration, } \\
\text { demonstration to } \\
\text { user, User's } \\
\text { suggestions and } \\
\text { feedback. }\end{array}$ & $\begin{array}{l}\text { Critical success factors in a Public } \\
\text { Sector Enterprise are level of } \\
\text { cooperation from both sides, more } \\
\text { user involvement and determination. }\end{array}$ \\
\hline 5 & $\begin{array}{l}\text { Sanjay } \\
\text { Mohapatra, } \\
2009\end{array}$ & $\begin{array}{l}\text { Framework for HRIS } \\
\text { Implementation in } \\
\text { Non-IT Sector. }\end{array}$ & $\begin{array}{l}\text { Case study, } \\
\text { interview. }\end{array}$ & $\begin{array}{l}\text { Along with management commitment, } \\
\text { communication with the employees, } \\
\text { including key people, keep project } \\
\text { team intact, involve significant } \\
\text { groups: important HRIS factors. }\end{array}$ \\
\hline 6 & $\begin{array}{l}\text { Sharna L. } \\
\text { Wiblen, } \\
\text { David and } \\
\text { Kristine } \\
\text { Dery, } 2010\end{array}$ & $\begin{array}{l}\text { Transitioning to a new } \\
\text { HRIS: the reshaping of } \\
\text { Human Resources and } \\
\text { information } \\
\text { technology talent. }\end{array}$ & $\begin{array}{l}\text { Case study, theory- } \\
\text { before-research } \\
\text { model of } \\
\text { investigation, semi- } \\
\text { structured in-depth } \\
\text { interviews. }\end{array}$ & $\begin{array}{l}\text { The selection and implementation of a } \\
\text { vendor provided HRIS was seen to } \\
\text { provide a number of benefits for the } \\
\text { organization. }\end{array}$ \\
\hline 7 & $\begin{array}{l}\text { H. Al Shibly, } \\
2011\end{array}$ & $\begin{array}{l}\text { Human Resources } \\
\text { Information Systems } \\
\text { Success Assessment: } \\
\text { An integrative model. }\end{array}$ & $\begin{array}{l}\text { Questionnaire, Field } \\
\text { study by experts and } \\
\text { researchers. }\end{array}$ & $\begin{array}{l}\text { The key consequents of HRIS success } \\
\text { are user-related, recognizing the } \\
\text { employee's important role in } \\
\text { determining the success of business } \\
\text { endeavors. }\end{array}$ \\
\hline 8 & $\begin{array}{l}\text { Indrit } \\
\text { Troshani, } \\
\text { Cate Jerram, } \\
\text { Sally Rao, } \\
2011\end{array}$ & $\begin{array}{l}\text { Exploring the public } \\
\text { sector adoption of } \\
\text { HRIS }\end{array}$ & Interviews & $\begin{array}{l}\text { Champions in public sector } \\
\text { organizations should demonstrate } \\
\text { HRIS benefits before their adoption } \\
\text { can succeed. }\end{array}$ \\
\hline 9 & $\begin{array}{l}\text { Christian } \\
\text { Maier, Sven } \\
\text { Laumer, } \\
\text { Andreas } \\
\text { Eckhardt, } \\
\text { Tim Weitzel, } \\
2012\end{array}$ & $\begin{array}{l}\text { Analyzing the impact } \\
\text { of HRIS } \\
\text { implementations on } \\
\text { HR personnel's job } \\
\text { satisfaction and } \\
\text { turnover intention. }\end{array}$ & Survey & $\begin{array}{l}\text { Individual-level consequences is a } \\
\text { dimension of HRIS implementation } \\
\text { success. The implementation of an } \\
\text { HRIS has a profound influence on the } \\
\text { employees in terms of job satisfaction } \\
\text { and turnover intention. }\end{array}$ \\
\hline 10 & $\begin{array}{l}\text { Dr. } \\
\text { Mohammed } \\
\text { Owais } \\
\text { Qureshi, Dr. }\end{array}$ & $\begin{array}{l}\text { A Comparative Study } \\
\text { of the Software } \\
\text { Packages Used as } \\
\text { HRIS by }\end{array}$ & $\begin{array}{l}\text { Questionnaire, } \\
\text { surveys }\end{array}$ & $\begin{array}{l}\text { For making sure that the HRIS being } \\
\text { implemented impacts human resource } \\
\text { management and the organization is } \\
\text { able to get the most out of the }\end{array}$ \\
\hline
\end{tabular}




\begin{tabular}{|c|c|c|c|c|}
\hline & $\begin{array}{l}\text { Syed } \\
\text { Rumaiya } \\
\text { Sajjad (2013) }\end{array}$ & $\begin{array}{l}\text { Organizations } \\
\text { Operating in India: } \\
\text { Human Resource } \\
\text { Professionals' } \\
\text { Perspective. }\end{array}$ & & $\begin{array}{l}\text { integration between the two the } \\
\text { human resource information system } \\
\text { should be user friendly and less } \\
\text { complicated to use. }\end{array}$ \\
\hline 11 & $\begin{array}{l}\text { Sabrina } \\
\text { Jahan, } 2014\end{array}$ & $\begin{array}{l}\text { Human Resources } \\
\text { Information System } \\
\text { (HRIS): A Theoretical } \\
\text { Perspective. }\end{array}$ & $\begin{array}{l}\text { Interviews and } \\
\text { material study. }\end{array}$ & $\begin{array}{l}\text { Commitment of top management is } \\
\text { required to remove the existing } \\
\text { barriers to success of HRIS. }\end{array}$ \\
\hline 12 & $\begin{array}{l}\text { Nisha Gupta, } \\
\text { Ajay Kr. } \\
\text { Singh, Smrita } \\
\text { Sinha, Anita } \\
\text { Venaik, } 2016\end{array}$ & $\begin{array}{l}\text { Barriers to } \\
\text { Measurement of } \\
\text { Human Asset: An } \\
\text { Empirical Study of } \\
\text { Select IT sector } \\
\text { Companies in Delhi } \\
\text { and NCR. }\end{array}$ & Questionnaire & $\begin{array}{l}\text { There are barriers to the measurement } \\
\text { of Human Asset and believe that there } \\
\text { are lack of understanding of the } \\
\text { measures by others in the } \\
\text { organization, uncertainty as to what } \\
\text { information should be reported and } \\
\text { that current human resource measures } \\
\text { lack precision. }\end{array}$ \\
\hline 13 & $\begin{array}{l}\text { Md. Abdullah } \\
\text { Al Mamun, } \\
\text { Md. } \\
\text { Shamimul } \\
\text { Islam, } 2016\end{array}$ & $\begin{array}{l}\text { Perception of } \\
\text { Management on } \\
\text { Outcomes of Human } \\
\text { Resource Information } \\
\text { System (HRIS) }\end{array}$ & $\begin{array}{l}\text { Related literature } \\
\text { review }\end{array}$ & $\begin{array}{l}\text { A firm can avail the boon of HRIS in } \\
\text { those areas with the commitment, } \\
\text { decisions and actions of management. } \\
\text { Thus, management support is the key } \\
\text { to HRIS formulation and execution in } \\
\text { a firm. }\end{array}$ \\
\hline 14 & $\begin{array}{l}\text { R.H. Al- } \\
\text { Dmour, R. } \\
\text { Masa'deh, } \\
\text { B.Y. Obeidat, } \\
2018\end{array}$ & $\begin{array}{l}\text { Factors influencing the } \\
\text { adoption and } \\
\text { implementation of } \\
\text { HRIS applications: are } \\
\text { they similar? }\end{array}$ & Interviews, surveys & $\begin{array}{l}\text { A better understanding of adoption of } \\
\text { HRIS behavior and the level of } \\
\text { implementing of HRIS applications } \\
\text { requires that the firms' environmental } \\
\text { factors be viewed as whole. }\end{array}$ \\
\hline 15 & $\begin{array}{l}\text { A. N. } \\
\text { Fobang, S. F. } \\
\text { Wamba, } \\
\text { J. R. K. } \\
\text { Kamdjoug, } \\
2019\end{array}$ & $\begin{array}{l}\text { Exploring Factors } \\
\text { Affecting the } \\
\text { Adoption of HRIS in } \\
\text { SMEs in a Developing } \\
\text { Country: Evidence } \\
\text { from Cameroon. }\end{array}$ & Questionnaire & $\begin{array}{l}\text { Performance Expectancy and Internal } \\
\text { Social Influence have a significant } \\
\text { effect on the intention to adopt HRIS. }\end{array}$ \\
\hline
\end{tabular}

Research Gap Identification: By reviewing earlier research work, we notice that many researchers have described various industries regarding the HRIS implementation. Some of them have even evaluated the success factors in public sectors and private sectors. The success factors of HRIS, and the challenges faced during HRIS implementation are also studied. But it is still unclear if the success factors of HRIS ensures employee's satisfaction and personal growth. All organizations with successful HRIS may not have fully satisfied employees. Moreover, it is not sure if the implemented HRIS will enhance the skillsets and growth of any employee. May be HRIS is beneficial from organization's point of view but which factors will develop employee's competencies is still unknown.

\section{RESEARCH METHODOLOGY}

\subsection{Research Objective}

To identify the factors that sustain employee's satisfaction and skills along with accomplishing a successful HRIS implementation.

\subsection{Research Question}

Will the factors associated with a successful HRIS implementation also help in maintaining employee's satisfaction and 
skills?

\subsection{Research Design}

The research design type of this study is descriptive in nature.

\subsubsection{Number of Participants}

Sample Size: The total number of participants in this study is 70 .

Sample Location: 2 Indian public sector companies. (Noida, UP \& Sivasagar, Assam).

\subsubsection{Data/Interview Collection:}

Both quantitative and qualitative type of research approach.

\subsubsection{Sources of Collecting Data:}

Secondary Sources: Journals on HRIS, HRM, employees' satisfaction, Internet sources.

Primary Sources: Data provided by the employees through questionnaire. Lesser number of responses was collected for this study because time-period for data collection was strictly limited.

\subsubsection{Instrument Used:}

Data collection Tool: E-questionnaire. Participants belong to middle and lower levels. Out of 80 questionnaires, 70 were selected. These 45 participants include middle and lower level of management in the organization. Confidentiality was guaranteed to the respondents.

Data Analysis Tool: SPSS and Microsoft Excel.

\subsubsection{Variables:}

Dependent Variable: Impact of a successful HRIS on employees' growth

Independent Variable: i) top management support, ii) skillsets of employees iii) organizational structure, iv) feedback from employees v) challenge for employees

\subsubsection{Hypotheses:}

Null hypothesis (H0): A successful HRIS does not sustain employees' satisfaction and growth.

Alternative hypothesis_(H1): A successful HRIS can sustain employees' satisfaction and growth.

\section{DATA ANALYSIS}

1) Satisfaction of the employees with the HRIS:

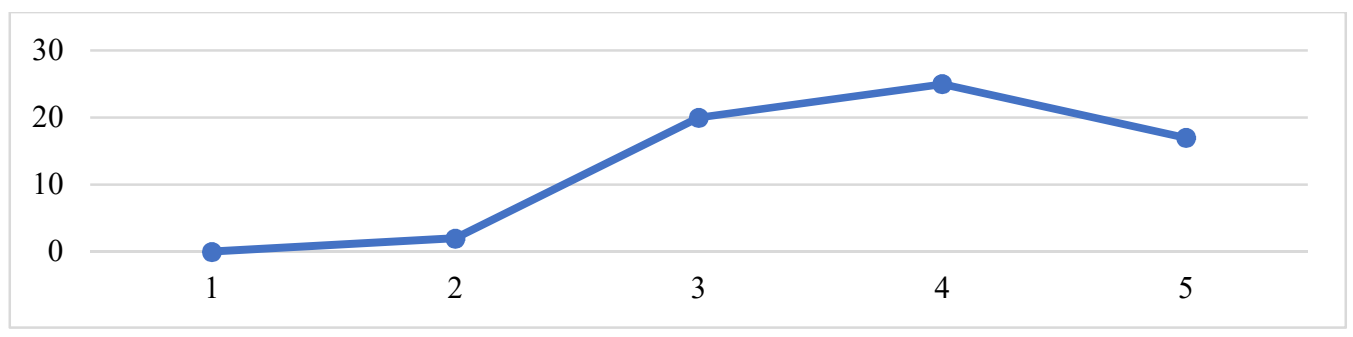

Figure 1: Ranking the company's HRIS by the participants 
Interpretation - This shows that even if the 2 organizations have successfully been using HRIS for so many years, still the employees are not satisfied with the system. This may be because the employees' personal growth and utilization of their domain skills are missing.

\section{2)Preference between HRIS and automated HR system:}

Table 2: Relationship between two selected variables

\begin{tabular}{|c|c|c|c|}
\hline \multicolumn{4}{|c|}{ Correlations } \\
\hline & & $\begin{array}{c}\text { Which is more } \\
\text { preferable? }\end{array}$ & $\begin{array}{c}\text { What is the biggest } \\
\text { challenge faced } \\
\text { during HRIS } \\
\text { implementation? }\end{array}$ \\
\hline \multirow[t]{3}{*}{ Which is more preferable? } & Pearson Correlation & 1 & .183 \\
\hline & Sig. (2-tailed) & & .129 \\
\hline & $\mathrm{N}$ & 70 & 70 \\
\hline \multirow{3}{*}{$\begin{array}{l}\text { What is the biggest challenge faced } \\
\text { during HRIS implementation? }\end{array}$} & Pearson Correlation & .183 & 1 \\
\hline & Sig. (2-tailed) & .129 & \\
\hline & $\mathrm{N}$ & 70 & 70 \\
\hline
\end{tabular}

Interpretation - Most of the employees preferred implementing a completely new HRIS over automating their old HR system. It may depend on the challenges faced while implementing HRIS. May be the employees that had to deal with a lot of challenges will rather automate their old HR system instead of investing so much on new HRIS.

\section{3)Importance given to Employees' skillsets Enhancement:}

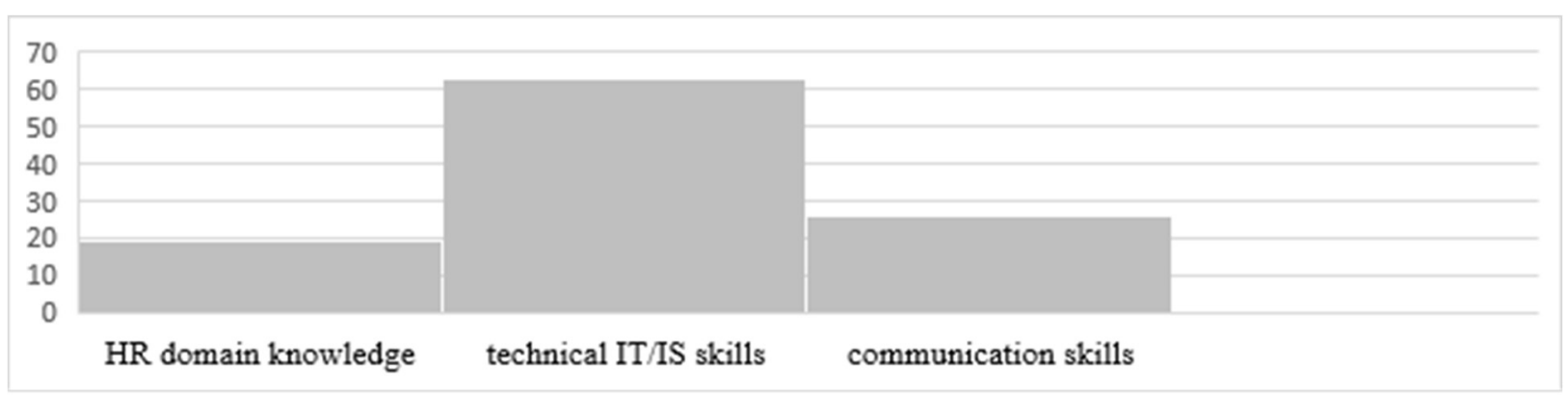

Figure 3: Required skillsets before HRIS implementation

Interpretation -The participants ranked Technical IT-IS skills as the most important required before implementing HRIS in an organization. This draw attention to the fact that may be the HR domain people shall not be fully benefited by the HRIS. If the employees are not able to utilise their skills and the HRIS does not enhance their skills their growth will cease at some point of time.

4)Importance of Organizational Size:

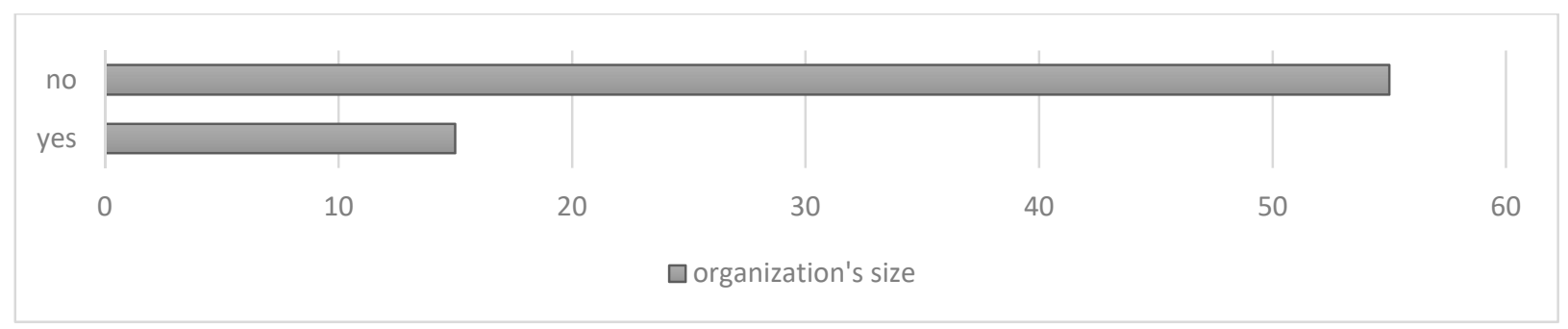

Figure 4: Importance of organizational size for HRIS 
Interrpretation - According to most of the participants, organizational size does not impact the success or failure of HRIS implementation. As per many recent researchers, even startups and small-medium enterprises are able to implement HRIS in their organizations. Earlier, only government-owned companies or big multi-national companies were able to implement HRIS.

5)Time period required for HRIS implementation:

Table 3: Time period required for HRIS implementation

\begin{tabular}{|l|l|l|l|l|l|}
\hline \multicolumn{5}{|c|}{ ANOVA, } \\
\hline \multicolumn{1}{|c|}{ Source } & \multicolumn{1}{|c|}{ Sum of Squares } & \multicolumn{1}{c|}{ df } & \multicolumn{1}{c|}{ Mean Square } & F & Sig. \\
\hline Regression & 12.719 & 3 & 4.240 & 5.938 & .001 \\
\hline Residual & 47.124 & 66 & 714 & & \\
\hline Total & 59.843 & & & \\
\hline \begin{tabular}{l} 
a. Dependent Variable: How much time period is required to fully computerized a HR system? \\
\hline
\end{tabular} \\
$\begin{array}{l}\text { b. Model: (Intercept), Management commitment was considered to be a key driver for the successful } \\
\text { implementation of HRIS., Does feedback play an important role in determining the success of an HRIS?, Is } \\
\text { recruitment of new employees an essential step to ensure HRIS success? }\end{array}$ \\
\hline
\end{tabular}

Interpretation -According to the participants, the time require to completely implement HRIS is around 1 to 2 years. Such a big investment of time for HRIS has to be done with prior planning and employees' involvement. The overall time period depends on various factors but mostly focus on involving the employees and priortising their needs and requirements.

\section{6)Importance of Management Commitment}

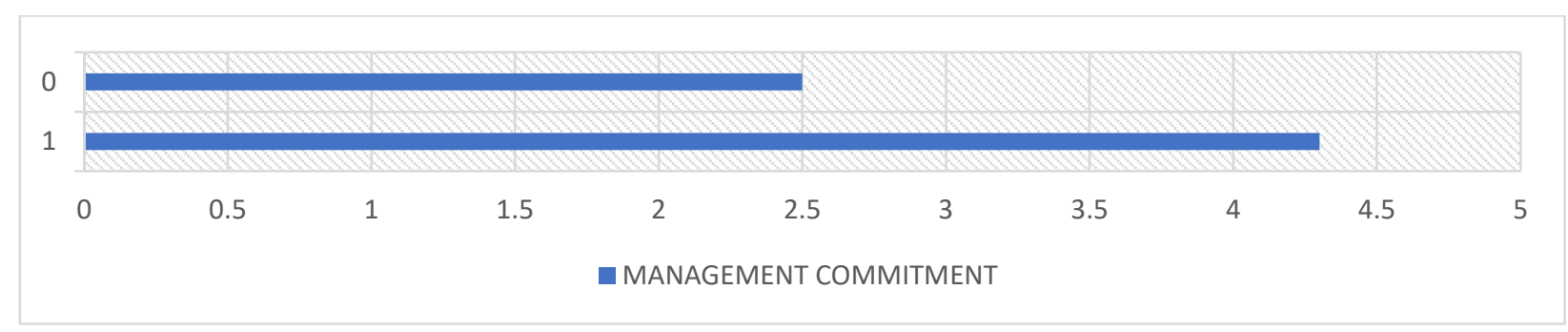

Figure 5: Importance of management commitment towards HRIS

Interpretation - Earlier researchers have focused on the importance of commitment from the management team in successful implementation of HRIS. In this study, when the participants are asked about the management commitment most of them agreed. It implies that management has to be the bridge between HRIS deliverables and employees' requirements. 
7)Factors affecting the HRIS implementation and the employees' satisfaction

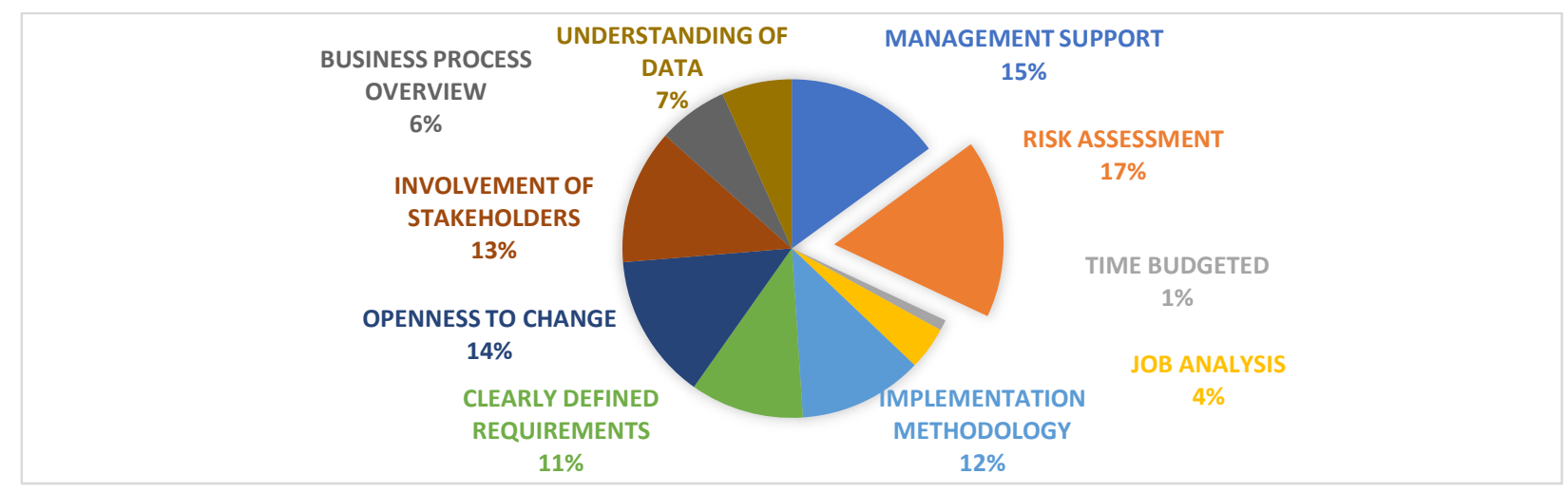

Figure 6: Probable factors influencing the implementation of HRIS.

Interpretation -In earlier research papers many factors are evaluated. Among these factors, the most important factors according to the participants is risk assessment. Risk assessment when linked to employees' satisfaction prove that employees may not be in favor of HRIS if they identify personal risks and stagnant growth.

8)Appropriate organizational structure for HRIS and the employees':

Table 4: Frequency of required organizational structure for HRIS.

\begin{tabular}{|l|l|c|c|c|c|}
\hline \multicolumn{6}{|c|}{ What should be the organizational structure in order to attain success in HRIS? } \\
\hline \multirow{4}{*}{ Valid } & Frequency & Percent & Valid Percent & Cumulative Percent \\
\cline { 2 - 6 } & centralised & 6 & 8.6 & 8.6 & 8.6 \\
\cline { 2 - 6 } & decentralised & 54 & 77.1 & 77.1 & 85.7 \\
\cline { 2 - 6 } & distributed & 10 & 14.3 & 14.3 & 100.0 \\
\cline { 2 - 6 } & Total & 70 & 100.0 & 100.0 & \\
\hline
\end{tabular}

Interpretation - According to the participants, organization with decentralized structure have the most chances of attaining success in their organization while implementing HRIS. The employees can put forward their opinions in decentralized structure and can focus on their personal growth. So. the structure of the organization is a big factor that can benefits the employees apart from attaining HRIS success.

\section{9)Contributors of HRIS:}

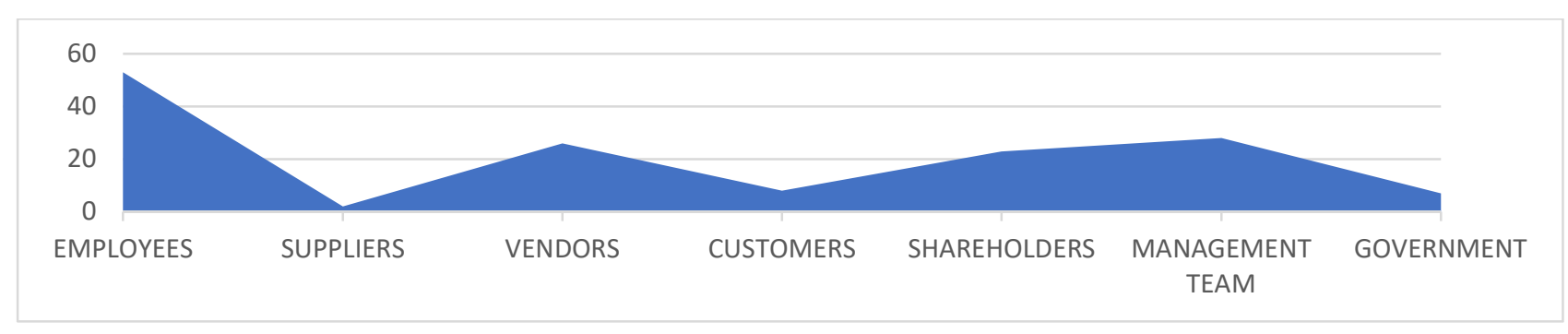

Figure 7: Contributors towards HRIS

Interpretation - The mostly chosen contributors for HRIS successful implementation are the employees. This clearly shows that the success of HRIS greatly depends on the employees. Even if the HRIS has been employed it can still be a failure lately, if the expectations of the employees are not met. The employees can provide contribution of they are 
satisfied with the system and are assured of their personal growth.

10) Importance of feedback from employees regarding their growth and needs:

(20\%

Figure 8: Importance of feedback in HRIS implementation.

Interpretation - Constructive feedback regarding the requirements, the objectives, the deliverables and the changes during the whole implementation process will surely help the implementors to properly execute their work. Feedback from the employees during the pre-implementation stage is always essential to get the reviews of the desired changes the organization would decide to make. This procedure is possible only if the organization has a decentralized structure where the employees can put forward their personal development from the new HRIS.

11) The stage that can help employees and bring HRIS success:

\begin{tabular}{|c|c|}
\hline $1 \%$ & $\begin{array}{l}\text {-PRE-IMPLEMENTATION STAGE } \\
\text { - } 33 \text { RESPONSES }\end{array}$ \\
\hline & $\begin{array}{l}\text {-IMPLEMENTATION STAGE } \\
\text { - } 8 \text { RESPONSES }\end{array}$ \\
\hline$\%$ & $\begin{array}{l}\text { - POST-IMPLEMENTATION STAGE } \\
\text { - } 29 \text { RESPONSES }\end{array}$ \\
\hline
\end{tabular}

Figure 9: Most importance stage of HRIS implementation

Interpretation - As per prior researchers, implementation of HRIS system has three main stages namely preimplementation, implementation and post-implementation stages. According to the participants, the most attention is required during the pre-implementation stage. This is because if there are any major error in this stage then the whole implementation process will be a failure. During the pre-implementation stage, the implementation team has to consider the expectations of the employees.

12) Challenges regarding the employees during HRIS implementation:

Table 4: Challenges faced by organizations during HRIS implementation.

\begin{tabular}{|c|c|c|c|c|c|}
\hline \multicolumn{6}{|c|}{ Bayesian Estimates of Coefficients ${ }^{\text {a,b,c }}$} \\
\hline \multirow{2}{*}{$\begin{array}{l}\text { What is the biggest challenge faced during } \\
\text { HRIS implementation? }\end{array}$} & \multicolumn{3}{|c|}{ Posterior } & \multicolumn{2}{|c|}{ 95\% Credible Interval } \\
\hline & Mode & Mean & Variance & Lower Bound & Upper Bound \\
\hline Top management reluctance. & 2.444 & 2.444 & .328 & 1.318 & 3.571 \\
\hline Lack of technological knowledge. & 3.200 & 3.200 & .590 & 1.689 & 4.711 \\
\hline
\end{tabular}




\begin{tabular}{|c|c|c|c|c|c|}
\hline Cost of infrastructural development. & 3.200 & 3.200 & .590 & 1.689 & 4.711 \\
\hline Difficult to maintain HRIS. & 3.909 & 3.909 & .268 & 2.890 & 4.928 \\
\hline Shortage of IT expert. & 3.250 & 3.250 & .738 & 1.561 & 4.939 \\
\hline Organizational internal resistance. & 3.667 & 3.667 & .984 & 1.716 & 5.617 \\
\hline Privacy issues for employees. & 5.667 & 5.667 & .984 & 3.716 & 7.617 \\
\hline Conversion cost. & 5.000 & 5.000 & 1.475 & 2.611 & 7.389 \\
\hline Ineffective ROI. & 4.846 & 4.846 & .113 & 4.184 & 5.509 \\
\hline \multicolumn{6}{|c|}{ a. Dependent Variable: What recommendations will you like to suggest ensuring effective implementation? } \\
\hline \multicolumn{6}{|c|}{ b. Model: What is the biggest challenge faced during HRIS implementation? } \\
\hline
\end{tabular}

\begin{tabular}{|l|c|c|c|c|c|c|}
\hline $\begin{array}{c}|c| \\
\text { What is the biggest challenge faced } \\
\text { during HRIS implementation? }\end{array}$ & Sum of Squares & df & Mean Square & F & Sig. & Bayes Factor \\
\hline Between Groups & 196.025 & 6 & 32.671 & 4.524 & .001 & 2.745 \\
\hline Within Groups & 440.490 & 61 & 7.221 & & & \\
\hline Total & 636.515 & 67 & & & & \\
\hline a. Bayes factor: JZS & & & & & \\
\hline
\end{tabular}

Interpretation - Prior research works have pointed out certain challenges commonly faced by the organizations. Among these challenges, the participants have chosen ineffective ROI as the primary challenge faced by the organizations. The ROI depend on the productivity of the employees and the workers. This indicates that even if the HRIS has been implemented in the organization it may not be profitable if the employees' satisfaction is not met. So, retention of employees decreases therefore resulting in ineffective ROI.

\section{3) Hiring new employees and its impact on existing ones:}

\section{NO - FROM 60 RESPONSES}

- If new employees are hired it means more costs and time. It can also hamper the morale of existing employees and cause conflicts.

\section{YES - FROM 10 RESPONSES}

- If new skilled employees are hired it can accelertate the implementation process and cut the training cost of existing employees.

Figure 10: Importance of new employees for HRIS. 
Interpretation - Many organizations seem to hire bulk of new employees in order to gain productivity from newly implemented HRIS. But as a result, more wastage of time and money is seen. When asked to the participants, most of them agreed the recruiting new employees is not an essential step in order to ensure success in HRIS implementation. If right kind of training is provided to the already existing employees, it is sufficient for the organization to increase productivity and success through HRIS.

\section{4)Important recommendations for effective HRIS:}

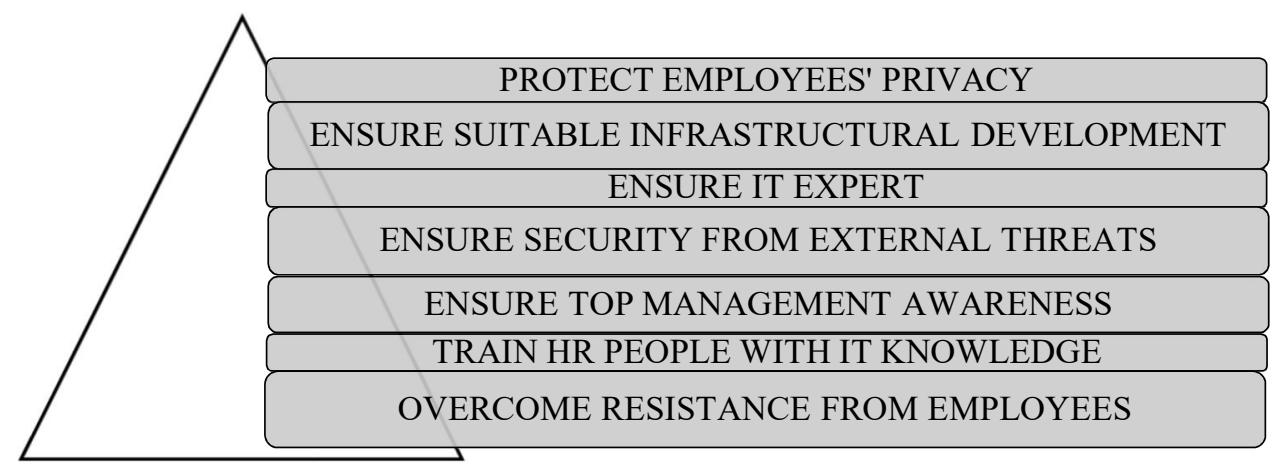

Figure 11: Some recommendations for effective HRIS implementation.

Interpretation - The participants highly suggested attention to - Overcome resistance from employees. These suggestions are based on the challenges the organizations faced during HRIS implementation. Employees being the greatest contributors to the HRIS and the biggest challenge being the ineffective ROI, the researcher can anticipate that feedback from the employees is important. The HRIS may align with the organization's goals but the employees may not find any personal benefit from the HRIS. Therefore, they may show reluctant to change. And if they are forced to use the HRIS, turnover of the organizations may increase resulting in the failure of the HRIS or extension of the overall time period. May be the organizations have to recruit new employees or invest on training the existing employees therefore increasing their expenses.

\section{FINDINGS}

- Overall quality of the HRIS was not the best for the 2 organizations. Even if the HRIS has been successfully implemented in those firms still the employees do not find it totally satisfying.

- Implementing a completely new HRIS was preferred over automating their old HR system. But it depends on the challenges and the requirement of the employees.

- Technical IT/IS skill of end-users is given importance in HRIS implementation. However, HR domain employees may suffer.

- Organizational size is not a success factor in HRIS implementation.

- Investment of approximately $1-2$ years is required for HRIS success.

- Management commitment is a success factor in implementation of a HRIS system.

- Risk assessment is anticipated to be a strong factor for successful HRIS. In order to assess risk, employees' 
requirements have to be taken care of.

- Decentralized organizational structure is important where the employees can put forward their opinions and requirements.

- Contribution from employees is top factor in HRIS implementation. This is possible only if the requirements of the employees are met.

- Constructive feedback can help in successful implementation of the HRIS. Along with organizational goals, feedback regarding employees' benefits has to be discussed.

- Utmost planning and execution during pre-implementation stage can result in successful HRIS implementation.

- Resolving primary challenge i.e. ineffective ROI can result in HRIS success. ROI can be better only if the employees gain productivity and satisfaction.

- Recruiting new employees is not a success factor in HRIS implementation. The existing employees can bring success only if their skills are fully utilised.

- Proper attention in order to overcome resistance from employees is important. Apart from implementing HRIS for organization's benefit, employees' self-growth and skills utilization is important.

\section{CONCLUSIONS}

Implementation of Human Resource Information Systems is a strategic level decision-making happening in a firm. Organizations may have been able to successful implement the HRIS, but the amount of ROI is not sure until the employees are satisfied. When correct organizational structure is maintained and proper feedback is taken from the employees then there is a possibility of desired ROI. Employees being the biggest contributors to HRIS success should be prioritized and their skillsets should be enhanced and utilised for their personal growth. This can result in no extra hiring cost and will overcome the resistance from the employees.

\section{LIMITATIONS}

First, results obtained from this study cannot be generalized due to the fact that only a considerable sample size was taken without including the top management. Second, the industry chosen for this study is Oil and Gas industry. The findings may be different if it is conducted in some other industry. The researcher had identified fewer factors. This study was conducted only 2 organizations constrain to 2 specific locations in India. Results vary from organizations to organizations. Another limitation can be the fact that the organizations that the researcher has chosen implemented HRIS long time back. It means the organization might have passed the initial failures of HRIS implementation. The organization has successfully developed during their HRIS implementation process. Analyzing the responses of the participants during the initial stages (less than one-year old HRIS system) may have varied the results.

\section{REFERENCES}

1. DeSanctis Gerardine. (March 1986), "Human Resource Information Systems: A Current Assessment". MIS Quarterly, Vol. 10, No. 1 pp. 15-27. 
2. Wolfe, M.N. (June 1978), "Computerization: It can Bring Sophistication into Personnel," Personnel Journal, Volume 57, Number 6, pp. 325-326.

3. E.A. Tomeski, and H. Lazarus. (August 1973a), "Information Systems in Personnel: Part I, "Journal of Systems Management, Volume 24, Number 8, pp. 18-21.

4. Ashbaugh, S., \& Miranda, R. (2002). Technology for human resources management: Seven questions and answers. Public Personnel Management, 31, 7 - 16. 2.

5. Bell, B.S., Lee, S.-W., \& Yeung, S.K. (2006). The impact of e-HRM on professional competence in HRM: implications for the development of HR professionals. Human Resource Management, 45 (3), 295 - 308. 3.

6. Bondarouk, T., \& Ruël, H. (2009). Electronic Human Resource Management: challenges in the digital era. International Journal of Human Resource Management, 20 (3), 505 - 514. 4.

7. Brown, D. (2002). eHR - victim of unrealistic expectations. Canadian HR Reporter, 15 (5), 1.

8. Broderick, R., \& Boudreau, J.W. (1992). The evolution of computer use in human resource management: interviews with ten leaders. Human Resource Management, 30 (4), 485 - 508.

9. Venkatesh, V., et al. (2003). User Acceptance of Information Technology: Toward a Unified View. MIS Quarterly, 27(3). 425478.

10. Voermans, M.Veldhoven, M.v. (2007). Attitude Towards E-HRM: An Empirical Study at Philips. Personnel Review, 36(6). 887-902.

11. Storey, J., Developments in the Management of Human Resources. 1992, Oxford: Blackwell.

12. BONDAROUK $T$ and RUEL HJM (2009) Electronic Human Resource Management: challenges in the digital era. International Journal of Human Resource Management 20 (3), 505 - 514.

13. Bhatnagar, J. (2009). Human resource information systems (HRIS) and HR outsourcing in India. In The changing face of people management in India (Eds). Routledge. London and New York.

14. Budhwar, P., \& Boyne, G. (2004). Human resource management in the Indian public and private sectors: An empirical comparison, International Journal of Human Resource Management, 15 (2), 346-370.

15. Friedman, B. (2008). Globalization implications for human source management roles. Employee Response Rights Journal, 19:157-171.

16. Nisha Gupta, Ajay Kr. Singh, Smrita Sinha, Anita Venaik, (Jul-Dec 2016). "Barriers to Measurement of Human Asset: An Empirical Study of Select IT sector companies in Delhi and NCR". Amity Business Review. Vol 17. Issue 2. P125-131. 4p. 

